\title{
OFFICIAL INDUCEMENTS TO PLEAD GUILTY: SUGGESTED MORALS FOR A MARKETPLACE
}

The criminal defendant is frequently subjected to official inducements to plead guilty. These inducements are necessary to the effective administration of the criminal process, ${ }^{1}$ but some pose a threat to the constitutional rights of the defendant. A tension results, and guidelines for official behavior are needed. In an effort to resolve the tension, this comment will examine the specific impact of each type of inducement on the defendant, ${ }^{2}$ in light of constitutional standards of waiver.

1 The calendar problem is familiar. That inducements are offered to alleviate it seems clear. "[A] criminal court can operate only by inducing the great mass of actually guilty defendants to plead guilty, paying in leniency the price for the pleas." Lummus, The Trial Judge 46 (1987). See note 62 infra.

The "great mass" does plead guilty. From 1 July 1962 through 30 June 1963, 34,845 criminal defendants appeared in federal district courts, of whom 25,924 , or about 75 per cent, pleaded "guilty" or "nolo contendere." ANNUAL RePORT OF THE Director OF the AdMinistrative OfFice of the United States Courts-1963, p. 240.

Inducements to plead guilty are not the only possible answer to the calendar problem, although they appear to be the most practical solution. One alternative would be the increase of prosecuting and judging facilities to the point at which they could handle trials of all indicted defendants. In the federal courts, on the basis of the above figures, the facilities would have to be quadrupled. Such increase may quickly exhaust the qualified talent available and the result might be an overall decline in the level of performance of officials. Alternatively, requiring all defendants to go to trial, but without the increase in facilities, would result in delays, rushed and cursory treatment of cases and resulting possible denials of constitutional rights.

Another possible solution would be to have prosecutors simply prosecute fewer people, but require all of them to go to trial. In light of the reputedly small percentage of people who commit crimes who are indicted, perhaps a substantial decrease in the number prosecuted would be comparatively insignificant.

None of these alternatives, however, appear likely to be adopted in the near future.

2 Almost all of the cases discussed here deal with pleas of guilty in federal courts by defendants charged with federal crimes. A defendant who thinks his plea was unconstitutionally induced must petition to the trial court for a hearing under 28 U.S.C. § 2255 (1958). The circuit courts ordinarily hear these cases only when a hearing below is denied on the grounds that the claim is frivolous, or when relief is denied after a hearing. They decide whether the claim has constitutional merit and, if it does, the case is returned to the district court for a $\S 2255$ hearing. Most of the cases here discussed deal with comments by appellate courts in determining whether the facts alleged raise a constitutional question.

Though state cases are not discussed here in significant numbers, it appears that state courts will be held to the same standards as the federal courts. Cases involving state proceedings and cases involving federal proceedings cross cite 


\section{Prosecutor Induced Pleas}

The ordinary standard for waiver of a constitutional right is that the waiver must be knowing and voluntary. ${ }^{3}$ Since a plea of guilty constitutes a waiver of the constitutional right to a trial, it must conform to this standard. One or the other requirement is referred to in most cases on induced guilty pleas, and the Federal Rules of Criminal Procedure provide that a judge shall not accept a plea of guilty "without first determining that the plea is made voluntarily with understanding of the nature of the charge." 4 It is the content of each requirement that must be defined.

\section{A. A Knowing Plea}

Knowing is a relatively clear concept. It has a common meaning which can be usefully applied to the facts of these cases: The inducement used by the prosecutor must not contain false or misleading information..$^{5}$

When inaccurate information, whether the fruit of deceit or of mistake, serves as the basis for the guilty plea, the plea ought to be voided. In Machibroda $v$. United States, ${ }^{6}$ the defendant alleged that the prosecutor had promised him no more than twenty years, a comparatively

each other without comment. This suggests that a constitutional due process standard is being applied in both and that the federal trial courts are not being held to a special standard under the supervisory power of higher federal courts. See United States ex rel. McGrath v. LaVallee, 319 F.2d 308 (2d Cir. 1963), United States ex rel. Wissenfeld v. Wilkins, 281 F.2d 707 (2d Cir. 1960).

3 The language varies. See Johnson v. Zerbst, 304 U.S. 458, 464 (1938): "A waiver is ordinarily an intentional relinquishment or abandonment of a known right or privilege." The Court also speaks of an "intelligent and competent waiver." $I d$., at 465. This case was followed in Von Moltke v. Gillies, 332 U.S. 708, 723-24 (1948). Cf. Kercheval v. United States, 274 U.S. 220, 223 (1927): "[C]ourts are careful that a plea of guilty shall not be accepted unless made voluntarily after proper advice and with full understanding of the consequences." Followed in Machibroda v. United States, 368 U.S. 487, 493 (1962) (dictum).

4 Fed. R. Crim. P. 11.

5 Von Moltke v. Gillies, 332 U.S. 708 (1948); Johnson v. Zerbst, 304 U.S. 458 (1938). In Edwards v. United States, 256 F.2d 707, 710 (D.G. Cir. 1958) the court said: "[W]e think 'understandingly' [in Rule 11] refers merely to the meaning of the charge, and what acts amount to being guilty of the charge, and the consequences of pleading guilty thereto . . . ." "Understandingly" is used synonymously with "knowing." The cases revolve around the defendant's possession of information about the charge. See United States v. Hetherington, 279 F.2d 792 (7th Cir. 1960). The discussion here is restricted to problems of knowledge of consequences of the plea.

6368 U.S. 487 (1962). The Court's discussion of the constitutionality of the plea is dictum. The case was remanded on the more narrow ground that the District Court had made findings on controverted issues of fact without the notice to petitioner and the hearing required by 28 U.S.C. $\$ 2255$ (1958). 
light sentence, if he would plead guilty. Defendant, represented by counsel, pleaded guilty, but was sentenced to forty years in prison. The Supreme Court stated that on these facts the plea should be voided. In an opinion characteristic of induced guilty plea cases, no theory was offered in support of this result. The Court said only that the "guilty plea, if induced by promises or threats which deprive it of the character of a voluntary act, is void." 7 The content of this "voluntary" standard is not provided. ${ }^{8}$

The court might have avoided the elliptical rubric of the "voluntary" standard and provided a sounder analysis of the problem. The defendant's plea was based on information that a plea of guilty would result in a twenty-year sentence. Since that information turned out to be inaccurate, the case would have been resolved more soundly on a theory of knowing plea and the opinion might have more carefully identified the operative facts that required voiding of the plea. ${ }^{9} \mathrm{Had}$ the information been accurate, and had the promise been kept, no knowing plea problem would have arisen.

However, merely demonstrating that a guilty plea is based on inaccurate information may not be sufficient to void the plea. Since in Machibroda, as in most cases, the prosecutor was probably not in a position to actually make good on a sentencing promise, his promise

\section{Id. at 493.}

8 In Motley v. United States, 230 F.2d 110 (5th Cir. 1956), the judgment was vacated on facts similar to those in Machibroda, without resort to any standards, ambiguous or otherwise. The Court simply quoted: "Under the allegations here petitioner is entitled to relief if he can prove his charges." Id. at 112. See also Teller v. United States, 263 F.2d 871 (6th Cir. 1959), where the prosecutor promised that he would not prosecute defendant's girl friend if defendant pleaded guilty. The prosecutor got the defendant's guilty plea and the girl friend got ten years. The court found a "possible infringement of the constitutional rights of the appellant." Id. at 872. Not only was this plea not a knowing plea because it was based on information that was inaccurate, but it was also an involuntary plea. See Section I-b infra.

9 Compare Smith v. O'Grady, 312 U.S. 329 (1941), in which the Court did treat the case as one of "deception." The deception here was more obvious than in Mrachibroda. State law enforcement officers told the defendant that if he would plead guilty he would be treated "leniently." A light sentence was agreed to in a telephone conversation purportedly with the assistant prosecutor but not, in fact, with him. The defendant pleaded guilty and received a heavy sentence. The Court reversed for many violations of due process including the fact that the defendant "because of deception by the state's representatives... had pleaded guilty ...." Id. at 334 .

If the inaccuracy of the information is the operative factor in these cases, then the voluntary plea requirement is inapplicable on its face. Since "voluntary" refers to the state of the defendant's will at the time of his plea, it should be possible to determine whether the plea was voluntary immediately after it is made by looking at the circumstances in which it was made. But here, the plea is void because of something that occurs at a later time. 
is on its face unreliable. While defense counsel could not assist his client in determining whether the content of the promise was accurate, he could have told his client that the prosecutor did not have the power to keep his promise. ${ }^{10}$ In United States ex rel. Wissenfeld $v$. Wilkins, ${ }^{11}$ the court held that even where the substantive content of the prosecutor's promise is inaccurate, there may be no constitutional problem, "particularly where defendant is represented by counsel or is experienced in the ways of the criminal courts ...."12 The court found that the defendant before it "must be supposed to know . . . that such a promise is in no way binding upon the court and ought not to affect the prisoner's judgment in pleading." 13

Nonetheless, it is possible that the defendant will rely on the promise. Where there has been reliance in fact on the false statement by the prosecutor, the plea ought to be voided as not a knowing plea. ${ }^{14}$ The fact of the plea of guilty under these circumstances suggests a failure to heed counsel's information and reliance on the false statement. In order to protect the defendant, the fact of reliance ought to be a presumption to be rebutted by the prosecutor, no doubt a very difficult burden of proof to maintain. The result is likely to be that few pleas entered following a prosecutor promise of sentence will withstand attack. The desirable consequence may be the ultimate abandonment of the practice by prosecutors.

Consequently, a case might arise in which the prosecutor has deceived the defendant but in which the plea would be allowed to stand: the case in which the defendant, peering through the ruse, ignores the

10 A defendant must have counsel when he pleads guilty. Von Moltke v. Gillies, 332 U.S. 708, 721 (1948); Walker v. Johnston, 312 U.S. 275 (1941). FED. R. CRIM. P. 44 provides for the assignment of counsel to represent defendant "at every stage of the proceedings," including, presumably, the pleading stage. For state courts, the same rule applies. United States ex rel. Durocher v. LaVallee, 330 F.2d 303, 308 (1964). See also White v. Maryland, 373 U.S. 59 (1963); Uveges v. Pennsylvania, 335 U.S. 437, 442 (1948); Anderson v. North Carolina, 221 F. Supp. 930 (W.D.N.C. 1963). Defendant can waive this right provided the waiver is knowing and voluntary. Walker v. Johnston, supra. See also Comment, 31 U. CHI. L. REv. 591 (1964).

11281 F.2d 707 (2d Cir. 1960).

12 Id. at 712.

13 Ibid. The problem is similar where the prosecutor threatens what he cannot do. In United States v. Taylor, 303 F.2d 165 (4th Cir. 1962), the prosecutor threatened a severe sentence if the defendant went to trial. Held, the plea should be voided. See also Bone v. United States, 277 F.2d 63 (8th Cir. 1960), where the prosecutor promised to have some state charges against the defendant dropped if the defendant pleaded guilty. Defendant knew that there were no state charges, however, and thus knew that the promise was meaningless. The court had no trouble finding that the plea of guilty was valid.

14 In Smith v. O'Grady, 312 U.S. 329 (1941), the Court phrased its opinion in terms of reliance in fact. 
promise. This sanction of the prosecutor's deceit seems shocking on its face. However, it is a constitutional, not an aesthetic standard that is to be employed, and the question remains: What constitutional function would be served by voiding pleas where the defendant, despite the deception, has not relied in fact?

A possible function is the deterrence of prosecutor deception; it is on this basis that convictions are reversed in the search and seizure cases. ${ }^{15}$ This argument, however, is inapplicable here because the objectionable acts are distinguishable. Since the Constitution prohibits the illegal search or seizure itself, the resulting evidence is excluded because that is the only practical way of implementing the constitutional standard. ${ }^{16}$ But not all prosecutor deception is prohibited by the Constitution. ${ }^{17}$ Only when the consequence of the prosecutor's deception is a plea of guilty that is not knowing, does the case raise a constitutional question. Consequently, the deterrence argument cannot support a per se rule of reversal whenever prosecutor deception occurs, since some convictions without constitutional infirmities would be reversed.

Prosecutor deception may nonetheless run afoul of the standard administered by the Supreme Court through its supervisory power over the lower federal courts. ${ }^{18}$ However, such a non-constitutional standard cannot be binding on state courts because federal courts do not have the jurisdiction to review state court convictions on deterrence grounds alone. In state cases the Court will be restricted to the constitutional knowing requirement. ${ }^{19}$

The Court in Machibroda, though finding an infringement of defendant's rights despite the presence of counsel, ventured no analysis of defendant's reliance on the prosecutor's promise. The Court, in fact, may have been responding to still another wrinkle in the problem, one which at least received glancing mention in the Court's statement of the facts. Defendant alleged that the prosecutor had said, when promising the light sentence in exchange for a guilty plea, that the promised sentence had the approval of the district judge. ${ }^{20}$ If that were in fact so, the prosecutor's promise was not deceitful and the

15 Mapp v. Ohio, 367 U.S. 643 (1961).

16 Id. at 655-56.

17 Compare, Note, 31 U. Chi. L. Rev. 313 (1964).

18 Mallory v. United States, 354 U.S. 449 (1957); McNabb v. United States, 318 U.S. 332 (1943). See Note, 76 HARv. L. REv. 1656, 1664-67 (1963).

19 It may be argued as well that deception by the prosecutor "shocks the conscience" and therefore constitutes a violation of due process. Query whether the conscience is shocked if the defendant ignores the prosecutor.

20368 U.S. at 489. 
argument above suggesting a constitutional violation would not hold. However, if the defendant were to receive a sentence other than the one promised, the plea would still not be a knowing plea, and ought to be voided.21 On the other hand, if there were in fact no judge authority, the prosecutor's statement was deceitful and can be subjected to the same analysis as proposed above.

In contrast to the above cases, it is difficult to see how a defendant has been hurt if he receives the sentence he was promised. These situations are more like the cases of prosecutor bargains, discussed below, than the cases of deceptive promises of leniency. The defendant may argue that he thought the prosecutor's promise had judicial authority behind it and that he relied on the statement as a judicial one. Under the general proscription of judicial pre-plea bargaining or promising, suggested below, even when the promise is kept, the defendant might obtain an additional avenue for reversal by proving that the reliance was reasonable and showing that the promise should be viewed as a judge promise.

The fulfillment of a promise does create at least a mild presumption of judicial involvement. If the judge assents to a promise made by the prosecutor, even after the promise is made, judicial involvement is clear. Insulation of the judiciary from plea-bargaining, a process with adversary overtones, is necessary to avoid later possible prejudice at trial if the defendant refuses to plead guilty. That insulation is possible only if these indirect judicial involvements are eliminated as well as the direct judicial bargaining, proscribed under the arguments below. Since it is unlikely that a prosecutor's sentence promise can be kept 'without at least some indirect judicial participation, fulfillment of the promise might be regarded as evidence of judicial authority behind the promise.

The consequence of this, however, is that of the two kinds of prosecutor promises, both turn out to be objectionable. One kind, where there is no judicial authority, is bad because deceitful. The second kind, where there is judicial authority, is bad because of the judicial authority. All that remains is the promise without judicial authority, upon which the defendant does not in fact rely, and that is of little utility to the prosecutor. The result may be that prosecutors will find little reason to resort to this inducement technique.

Courts tend to void guilty pleas only when the prosecutor has made a promise, a word that is strictly construed. "There is a considerable difference between an official expressing an 'opinion' as to what sentence a prisoner might receive and his making a 'promise' that if the prisoner

21 It should be treated as a judge promise. See Section II infra. 
will plead guilty he will receive a certain sentence." 22 Where there is no promise, no problem arises because the defendent should know, from the nature of the prosecutor's statement, that the sentence "predicted" cannot be relied upon.23

Where the prosecutor's inducement is not a promise or a prediction of the sentence actually to be imposed, but a bargain or agreement to do something within his power, the standard of truth should be adhered to but the problem is different. Here the only possible deception that can occur is when the prosecutor fails to keep his bargain. Even here the threat to the defendant is minimal, since most prosecutor bargains rest on agreements to do something before the plea is entered; the defendant consequently can refuse to plead guilty if the prosecutor does not perform.

The knowing plea problem, however, may arise in still another form. As in Dillon v. United States, ${ }^{24}$ the prosecutor's statement may be deceptive although not, strictly speaking, false. There, the prosecutor told the defendant that if the defendant pleaded guilty, the prosecutor would recommend a lenient sentence if the judge asked for a recommendation. At the time he made the bargain, however, the prosecutor knew that the court before which the defendant would appear never asked. The reviewing court found the prosecutor's bargain "wholly illusory" and said that a "plea induced by promises not intended to be kept would violate due process ...."25 In fact, however, the prosecutor not only intended to keep his promise but did keep his promise. The reason the plea in this case was not a knowing plea was because the defendant did not know the true nature of what he was getting in exchange for his plea. Had he known the court's practice, and nonetheless pleaded guilty, the plea would have been knowing. ${ }^{26}$

22 United States v. Wallace, 217 F. Supp. 518, 523 (W.D. Tex. 1963). Accord, Holt v. United States, 329 F.2d 368, 371 (7th Cir. 1964); Bryant v. United States, 189 F. Supp. 224 (D.N.D. 1960).

23 The distinction may not withstand the heat and light of reality. A correct prediction may bear some inference of judicial collusion and come very close to the promise discussed above. But the defendant ought not to be denied every scrap of relevant information; sound predictions of judicial sentencing behavior can be of great importance in weighing pleas.

On the knowing plea problem, generally, the same questions arise. If the prosecutor gives the defendant incorrect information on the statutory range of sentence that can be imposed on a plea of guilty, the resulting plea should be voided. If the information is corrected by the judge, however, the plea should stand. In United States ex rel. Farnsworth v. Murphy, 254 F.2d 438 (2d Cir. 1958), rev'd, 358 U.S. 48 (1958), jail officials told the defendant that the case would be treated as a misdemeanor, but it was not. The circuit court found the allegations frivolous, but the Supreme Court reversed and remanded for a hearing.

24307 F.2d 445 (9th Cir. 1962).

25 Id. at 449.

26 Defendant was not represented by counsel, who might have told the de- 


\section{B. A Voluntary Plea}

Guilty pleas may "pass" the knowing plea test, but may still be objectionable under the voluntary plea test. This requirement, sometimes viewed by the courts as a question of "coercion," is less clear than that the plea be knowing. Most courts have been content to define "involuntariness" as being a violation of due process, but have failed to supply specific guidelines for making determinations on any given set of facts. A coherent rationale which provides general predictive principles is needed.

The voluntary plea requirement does admit of clear formulation in one small group of cases-those in which a guilty plea is induced by actual or threatened physical force. ${ }^{27}$ These cases are extreme and their facts suggest that the decision of the defendant to plead guilty does not conform to a quite ordinary idea of "voluntariness." 28 Consequently such pleas should be voided.

Most cases require further analysis. The approach suggested here requires interpreting and applying the voluntary plea requirement in terms of two included problems: the threat to the defendant that if he does not plead guilty, his trial will be an unfair trial (for example, the judge will be prejudiced, perjured testimony will be introduced); and, the threat to the defendant that if he does not plead guilty, he will be subjected to a more severe punishment if he is convicted at trial than he would have been had he pleaded guilty-in effect, a punishment for going to trial.

In the cases of prosecutor inducement the threat of an unfair trial rarely arises, since the prosecutor usually cannot control trial procedure.29 The threat of punishment for going to trial is, however, a more serious problem because the prosecutor has substantial influence in sentencing.

fendant that the promise was not much of a promise. Whether this kind of subtle knowledge can be expected of defense counsel under a standard of normal competency and whether it, therefore, can be imputed to defendant is doubtful.

27 See Waley v. Johnston, 316 U.S. 101 (1942), where an FBI agent threatened to throw the defendant out of the window if he did not plead guilty. Held, the plea was coerced. The Court suggested that the standard for this case was the same as that for coerced confession cases. The rule also extends to torts and threatened torts. The FBI agent in Waley also threatened defamation. See Comment, The Coerced Confession Cases in Search of a Rationale, 31 U. Chi. L. Rev. 313 (1964).

28 Where the defendant's mental state is incompatible with voluntariness, the plea may be voided. See Frame v. Hudspeth, 109 F.2d 356 (10th Cir. 1940), rev'd, 309 U.S. 632 (1940), and remanded for a determination of defendant's mental competency at the time of the plea. Accord, Alexander v. United States, 290 F.2d 252 (5th Cir. 1961).

29 One exception is the case where the prosecutor knowingly uses perjured testimony with confidence that he will not be detected. 
The prosecutor can effectively present to the defendant differing sentence possibilities. Most guilty pleas are induced by prosecutor promises, bargains and compromises: In exchange for the plea the prosecutor agrees to dismiss some counts if there are multiple counts, or to allow a plea of guilty to a "lesser offense," an offense that carries a lighter penalty that the offense originally charged. ${ }^{30}$ The clear alternative facing the defendant in such circumstances is the possibility of a comparatively severe sentence after conviction at trial as against a relatively light sentence on a plea of guilty. ${ }^{31}$ Although such a threat may interfere with the right to a trial in the sense that it tends to persuade defendants not to go to trial, courts have not been moved to hold prosecutor bargains unconstitutional or the resulting pleas involuntary. 32 The question of the validity of these inducements is generally avoided ${ }^{33}$ or assumed away ${ }^{34}$ by the courts without discussion of the constitutional problems. ${ }^{35}$

30 A recent survey of the bargaining procedures employed by prosecutors suggests in some detail how the process operates. Note, Guilty Plea Bargaining: Compromises by Prosecutors to Secure Guilty Pleas, 112 U. PA. L. REv. 865, 896-908 (1964). The analysis, which goes well beyond the survey itself, suggests detailed guidelines for official behavior, although without substantial consideration of the constitutional questions raised by the problem of bargained pleas.

31 The distinction between a prosecutor's bargain to reduce charges and his promise to recommend leniency must be kept in mind. See United States v. Dillon, 307 F.2d 445 (9th Cir. 1962). The power to recommend should be subject to less question because it is less directly related to the final sentence and is clearly part of the prosecutor's role as an advocate. In Heidemann v. United States, 281 F.2d 805 ( 8 th Cir. 1960), the prosecutor told the defendant that he would try to get the maximum sentence at trial, but offered five years on a plea of guilty. The reviewing court found a "fearful threat" to the defendant and suggested that the prosecutor's action would require voiding the guilty plea. At first glance the decision seems wrong. The prosecutor was only saying what he would recommend and that, in effect, is only a promise to prosecute the case vigorously. The court may have been suggesting, however, that even this power of the prosecutor is hedged by some limits.

32 See Martin v. United States, 256 F.2d 345 (5th Cir. 1958), cert. denied, 358 U.S. 921 (1958); Shelton v. United States, 246 F.2d 571 (5th Cir.), rev'd on confession of error by the Solicitor General, 356 U.S. 26 (1958). Prosecutor bargains might be attacked via an equal protection argument. A defendant who gets a particularly severe sentence after conviction at trial, who can point to another defendant in apparently similar circumstances, who committed the same crime but who pleaded guilty and got a lesser sentence, might argue that the difference was based on plea alone and that the classification supporting the difference in sentences was not reasonable. See note 37 infra.

33 Tabor v. United States, 203 F.2d 948 (4th Cir. 1953), cert. denied, 345 U.S. 1001 (1953).

34 Anderson v. North Carolina, 221 F. Supp. 930, 934 (W.D.N.C). 1963.

35 Judge Rives of the Fifth Circuit provided a careful analysis of the problem in his dissent in Shelton v. United States, 246 F.2d 571, 577 (5th Cir. 1957), although he was not explicit on constitutional questions either. After observing that the majority had recognized that prosecutor's bargain, he said: "The very statement of that practice... concedes that such promises or commitments are inducements 
While these constitutional objections should be confronted, it is important to note that forbidding the inducements raises the substantial problem of crowded court dockets. Ideally, all defendants ought to be spared the pressure of prosecutor inducements because of the resulting interference with the right to trial. However, the primary focus of this constitutional protection is the innocent defendent. The current immunity of prosecutor bargains from judicial consideration can be justified only if the result is both to produce the needed guilty pleas and to persuade only guilty defendants to plead guilty. ${ }^{36}$

This immunity seems well justified because the prosecutor's threat is highly diluted. Not only does he lack power to sentence, but any influence he has over sentencing is filtered through the jury and the judgethe jury having the power to acquit on all or some of several counts, the judge having the power to sentence within a broad range including suspension and probation. The diluted threats therefore are most effective in the case of the guilty defendant. Before deciding on his plea the defendant weighs several variables, including the probability of conviction at trial and the sentences that may be imposed following either plea. The chances of acquittal by the jury are considerably higher for the innocent than for the guilty defendant. Such an assumption is required to support the use of the jury system. Thus, in his weighing of variables, the innocent defendant "multiplies" the risk of conviction "times" the severity of the threatened sentence, and arrives at a risk factor somewhat lower than that of the guilty defendant. The prosecutor can only threaten a fair trial with a fair sentencing procedure; for the innocent defendant, that is substantial protection. ${ }^{37}$

for the accused to plead guilty. Such inducements in any particular case may be sufficient to elicit an untrue plea of guilty . . . [I]f, on judical inquiry, the conclusion is that it was that promise, whether subsequentiy made good or not, that really brought about the guilty plea, then the plea was congenitally defective because it was the product of a decisive, potent, but extraneous force." Id. at 579. The analysis at least recognizes that there may be something wrong with the prosecutor bargain; however, it does not recognize the necessity for some tool of inducement.

36 Concern for the innocent defendant has prompted a suggested revision of FED. R. CRIM. P. 11 to read: "Notwithstanding the acceptance of a plea of guilty the court shall not enter a judgment upon such plea without making such inquiry as may satisfy it that there is a factual basis for the plea." The suggestion will be difficult to implement, in that it appears to require the trial court to make an initial determination of guilt before the trial. A more useful procedure, as suggested in this comment, would be to establish by careful analysis which official inducements are likely to induce the innocent defendant to plead guilty, and to eliminate those inducements from the criminal process entirely. To the extent that this solution does not eliminate all invalid guilty pleas the reviewing courts may still reverse in cases where the inducement, though not generally forbidden, is offensive in a particular case.

37 If similar defendants in similar circumstances are treated in different ways, 
The differentials that the prosecutor presents, however, may be so great as to induce even an innocent defendant to plead guilty. Clearly this is objectionable. ${ }^{38}$ Nevertheless, since the factual distinction between good and bad inducements involves a difficult evaluation of the subjective state of mind of the defendant at the time of the plea-the impact of the particular terms of the prosecutor's offer on the particular defendant-it may be argued that, given the relatively small risk to innocent defendants, all prosecutor bargains resulting in pleas that pass the knowing test ought to be permitted. Preferably, however, a flexible rule should be maintained under which the courts may void pleas in the rare cases in which the prosecutor's bargain has been so extreme as to give rise to the probability that an innocent defendant would have been induced to plead guilty.

Threats do not always relate to sentence, in which case the probabilities of inducing an innocent defendant to plead guilty increase. In Kent $v$. United States, ${ }^{39}$ the prosecutor told the defendant that unless a plea of guilty were entered the defendant's fiancée would be charged as an accessory. The defendant pleaded guilty and the prosecutor did not prosecute the girl. The reviewing court found no deprivation of rights in the inducement because "we are not prepared to say that it can be coercion to inform a defendant that someone close to him who is guilty of a crime will be brought to book if he does not plead. If a defendant elects to sacrifice himself for such motives, that is his choice." 40

an equal protection problem may arise. The equal protection argument can, however, be answered in several ways. First, it can be argued that the need of the criminal process for guilty pleas is so great that the classification of defendants by plea is a reasonable classification. More persuasively, it can be argued that the prosecutor bargain is simply a part of the general prosecutor discretion to control a case before it comes to trial. If the prosecutor can refuse to prosecute, or can choose to prosecute only for certain crimes, ignoring others, his bargaining seems only an extension of acceptable practices. If the prosecutor can refuse to prosecute, then perhaps a fortiori, he can prosecute ultimately for whatever crimes he chooses. Of course this argument merely pushes the consideration of constitutionality back further in the criminal process. For example, it may be asked, is it constitutional for a prosecutor to refuse to prosecute a defendant when he has prosecuted another defendant in the same or similar circumstances in the past?

38 Martin v. United States, 256 F.2d 345 (5th Cir.), cert. denied, 358 U.S. 921 (1958), suggests that there may be some limits on prosecutor discretion, but fails to note any case which so holds.

39272 F.2d 795 (1st Cir. 1959).

$40 \mathrm{Id}$. at 798. Threats to prosecute loved ones seem to be common. In Conley v. Cox, 138 F.2d 786 (8th Cir. 1943), the court grudgingly granted a hearing on allegations that the prosecutor had threatened prosecution of defendant's common law wife. See also United States v. Glass, 317 F.2d 200 (4th Cir. 1963), where the court remanded for a hearing to inquire into the "voluntariness" of the guilty plea. But the plea 
The court's analysis is inadequate. Besides the peculiar assumption that the "someone close to him" is guilty of a crime, the court throws protection of the innocent defendant and reliability of guilty pleas to the wind by allowing a "sacrifice" irrespective, apparently, of actual guilt. The defendant was threatened with punishment for going to trial and the threat was one that the prosecutor could keep. Since jury and judge could not temper the threat, the probabilities of acquittal were of no significance. Because both guilty and innocent defendants would be strongly persuaded by this threatened punishment, the court should have voided the plea.

Kent raises another non-sentencing problem. The prosecutor also indicated an intent to call the defendant's brother as a witness if the case went to trial. The court properly found no denial of due process in this threat since the inducement was nothing more than a promise to conduct a vigorous presecution. ${ }^{41}$ The threat of a trial, with all that it involves, cannot be regarded as an unconstitutional punishment for going to trial, for otherwise there would be no trials. ${ }^{42}$

Most bargains and compromises, because they do not pose a threat to the innocent defendant, are constitutional; these must be permitted in order to provide the criminal process with needed guilty pleas. But extreme threats that consistently induce the innocent defendant to plead guilty, raise substantial constitutional objections. ${ }^{43}$ Although a subjective test for voluntariness makes review of these cases difficult, that problem has not proved insuperable in other areas of criminal law administration, nor should it here. ${ }^{44}$

should have been voided as not a knowing plea: see note 8 and accompanying text supra. See also Teller v. United States, 263 F.2d 871 (6th Cir. 1959).

41 In Kent, the court responded to the further allegation that the prosecutor's promise to recommend a lighter sentence if the defendant pleaded guilty constituted coercion by saying that "petitioner must show that he was subjected to threats or promises of illegitimate action." 272 F.2d at 799. The court rightly did not regard prosecutor promises to recommend a certain sentence as a threat of illegitimate action. See Booth v. United States, 251 F.2d 296 (9th Cir. 1958). Similarly, threats of bringing certain witnesses to testify or of publicizing the trial are not threats of illegitimate action. But the test is not perfect. A threat of prosecuting Kent's finance was also not a threat of illegal action, but the resulting plea should nonetheless be held to be invalid. Furthermore, as suggested above (note 38 and accompanying text supra), there may be some limits on the prosecutor's power even to recommend, although all promises to recommend within the statutory limit of sentence must be regarded, in one sense, as legitimate.

42 Many pressures derive from contemplation of unpleasant experiences of trial, such as emotional and physical strain, expense, strain on family and time. These cannot be regarded as unconstitutional pressures operating against exercise of the right to trial; they are a consequence of having trials.

43 See note 35 supra.

44 Compare Comment, The Coerced Confession Cases in Search of a Rationale, 31 U. CHI. L. REV. 313 (1964). 


\section{Judge-Induced PleAs}

Judicially induced guilty pleas also may be analyzed in terms of the knowing and voluntary standards. The results, however, are somewhat different, largely because of the differing powers of prosecutors and judges.

\section{A. A Knowing Plea}

A plea based on inaccurate information provided by the judge should be void as not a knowing plea. ${ }^{45}$ Pleas made in response to promises by the prosecutor which is supported by the apparent authority of the judge are included here. Where the promise is of a specific sentence and a different sentence is imposed after the plea of guilty is entered, the plea should be voided as based on inaccurate information and therefore not knowing. Where the judge misinforms the defendant as to the statutory range of sentence, the plea entered on the basis of this information should also be voided. In Pilkington $v$. United States, ${ }^{46}$ the trial court explained to the defendant, who was represented by counsel, that the maximum sentence that could be imposed on a plea of guilty was five years. The defendant pleaded guilty and received an indeterminate sentence with a six year maximum from the same judge. The facts suggest that the judge had made an honest mistake. On appeal the court found that the defendant had been denied due process. Although this case clearly raises a knowing plea problem, the court reached its result by analyzing the problem in terms of "voluntariness." However, the court's mislabelling of the basic issue was mitigated by its observation that the controlling difficulty in the case was that the defendant had been "misled."47

The presence of counsel might suggest that the plea should have been upheld. Counsel should have been aware of the statutory sentence ranges and should have properly advised his client, and, if necessary, corrected the judge. Nonetheless, if the defendant relied on the judge's misstatement, the plea ought to be voided. Considering the imposing position of the judge, the defendant's reliance is almost a certainty.

\section{B. A Voluntary Plea}

Judicial comments to the defendant on sentencing must be analyzed in terms of the two questions offered above: Was there a threat to the defendant of an unfair trial? Was there a threat to the defendant of punishment for going to trial? Answers to these questions in cases of

45 For a detailed discussion of the knowing requirement, see Section I-a supra.

46315 F.2d 204 (4th Cir. 1963).

47 Id. at 207 
judge-induced pleas differ considerably from the answers in cases of prosecutor-induced pleas. This is required by the fact that while prosecutor inducements are substantially diluted by the prosecutor's lack of control over both trial and sentencing, judicial inducements are not. The judge presides at the trial and ultimately imposes sentence within a broad discretionary range. When he threatens either an unfair trial or punishment for going to trial, he can follow through on his threat.

In Euziere v. United States, ${ }^{48}$ the defendant alleged that the judge told him that unless he pleaded guilty the maximum sentence would be imposed after conviction at trial. The judge said that such a sentence would be justified because the defendant had put the government to the expense of a trial. On review, the court held that if the allegations were true, the defendant was entitled to have the judgment vacated. The court's explanation of its decision, a prime example of a result without a theory, has been quoted frequently by later courts in induced guilty plea cases:

Fundamental standards of procedure in criminal cases require that a plea of guilty . . . be entered freely, voluntarily, and without any semblance of coercion. A plea of guilty interposed as the result of coercion is not consistent with due process .... We think it is clear that the statements by the trial court were reasonably calculated to influence the defendants to the point of coercion into entering their pleas of guilty. ${ }^{49}$

The opinion would have been more helpful, and the result more understandable, had the court identified the facts that required the conclusion that the plea was "coerced," and had the relationship between those facts and a constitutional standard of behavior for the judge been identified. The innocent defendant, having heard the judge's statement, would be likely to be induced to plead guilty because the alternative of trial had been made highly unattractive: There was a threat of a severe sentence upon conviction. While the probability of acquittal may be as high here as in the case of a prosecutor threat, the risk of a severe sentence on conviction is increased because the judge is virtually unchecked in his sentencing power. Only the possibility of jury acquittal stands between threat and actuality. Compounding the innocent defendant's predicament is the fact that the probability of acquittal may itself be reduced under these circumstances because the judge may be unable to guarantee a fair trial. A judge who has already started thinking about the defendant's sentence before the trial begins, a judge whose frame of mind permits him to make a threat in the first place, may have

48249 F.2d 293 (10th Cir. 1957).

49 Id. at $294-95$. 
negated the presumption of innocence..$^{50} \mathrm{~A}$ perception of incipient unfairness as a result of the statement of the judge in Euziere would not be unreasonable. The innocent defendant, faced with this combination of threats, is likely to be induced to plead guilty.

An almost necessary implication of the judge's comment in Euziere is that if the defendant pleaded guilty, the maximum sentence would not be imposed, but, rather, a "lenient" sentence would result. This alternative was more explicitly presented by the judge in United States $v$. Tateo, ${ }^{\text {,1 }}$ where, after the trial had begun, the defendant, who was represented by counsel, was threatened with consecutive maximum sentences on several counts if the trial continued, and was offered some hope of leniency if he pleaded guilty. The reviewing court found that the plea should be voided because "to impose upon a defendant such alternatives amounts to coercion as a matter of law."52 Citing Euziere for the rule, the court followed the Euziere example by failing to offer a theory to explain the conclusion. The defendant here, like the defendant in Euziere, faced not only punishment for going to trial but the possibility of an unfair judge. Loading the trial alternative in this manner should be avoided because the innocent defendant is particularly vulnerable to this kind of threat.

In some cases a threat is hard to find. In Kimbrough $v$. United States, 53 the defendant, who was serving a prison term, was charged with another crime committed in prison. He and his counsel discussed the plea and sentence with the trial judge who, from the report of the case, seems to have been fatherly, kind and scrupulously fair.54 A specific lenient sentence was agreed upon in advance of the plea and was in fact imposed. The reviewing court found no denial of due process and observed that the defendant had "obtained by his plea a sentence greatly less than he could have been subjected to if convicted on a trial ...."55 The court's focus on the benefit to the defendant ignores the problem of inducing an innocent defendant to plead guilty, foregoing the protections of a trial. There is no such thing as a beneficial sentence for an innocent defendant.

The threat of severity on conviction at trial was in part mitigated

50 Defendant does have the remedy of review if the trial is in fact unconstitutional. But error of this kind is difficult to prove from a cold record. Furthermore, the defendant should not be required to face, in addition to a trial, an appeal to correct an unfair trial, with the additional expense that that entails.

51214 F. Supp. 560 (S.D.N.Y. 1963).

52 Id. at 567.

53226 F.2d 485 (5th Cir. 1955).

54 See $I d$. at 485 n.1.

65 Id. at 487. 
by the fact that the judge made a specific sentence commitment. Since a comparative as to sentence is not necessarily implied in this case as it is when the judge offers "leniency," the judge may be threatening only a fair trial and a fair sentencing procedure. The Kimbrough court found, however, that the sentence on trial would have been more severe; and the defendant can be presumed to have been aware of the fact. Whether there is a threat of severity in this case is difficult to determine. The fatherly judge may be so apparently fair in the defendant's eyes that the defendant sees no real danger of an unfair trial; thus the other threat that might induce the innocent defendant to plead guilty is not present.

A second very difficult determination of fact would be introduced if the appellate courts were required to separate fatherly judge cases from biased judge cases. In United States ex rel. McGrath 7 . LaVallee, ${ }^{56}$ the defendant, represented by counsel, had for several weeks refused to plead guilty. Finally, the trial judge held a conference attended by the defendant, the defendant's counsel, the prosecutor and a stenographer. The stenographic record of that conference reveals that the judge made the following comments to the defendant:

As I see it, the likelihood of your being acquitted is not too good. Of course, if you want a trial, you will certainly get a fair trial. But you must remember this: If you are convicted as a second offender of robbery in the first degree, you will be entitled to no consideration of any kind from me.

As I said, if the District Attorney proves the case as he has outlined, the likelihood of your being acquitted is not good. Or do you want to take a plea to robbery in the second degree and have some opportunity of receiving a shorter sentence? If I sentence you after a conviction of robbery in the first degree, you are going to be away until you are an old man. ${ }^{57}$

A divided court found on this record that there was no denial of due process. One majority judge interpreted the trial judge's remarks as "not . . . an enticement or threat by means of a prior commitment ... but . . . merely a fair description of the consequences attendant upon prisoner's choice of plea ...." 58 The dissenting judge vigorously argued that the case was an example of "judicial prejudgment" and a denial of due process. ${ }^{59}$

Assuming that the danger of prejudgment is vitiated by the assurance of a "fair trial" and the judge's solicitous manner, problems are raised

56319 F.2d 308 (2d Cir. 1963).

57 Id. at 323-24.

$58 \mathrm{Id}$. at 314 .

59 Id. at 321. 
by the majority interpretation that the judge was merely performing the legitimate function of advising the defendant on the real consequences, as opposed to only the statutory consequences, of either course of action. ${ }^{60}$ The judge who confines his comments to no more that a recital of the statutory limits of the consequences of either plea remains well within constitutional boundaries of action. When he begins to comment on the realistic consequences of either plea, he approaches the line of unconstitutionality, primarily because he has ultimate control over most of the reality upon which he comments. Delicate shading between comment and forecast and between forecast and threat makes the characterization of the comments difficult.

However, the consequences of the judge restricting himself to "safe" comments to protect the due process rights of the defendant are, paradoxically, to deny the defendant important and relevant information which might be helpful in choosing a plea. Such a rule enforces the defendant's due process right to plead in the dark. Since his choice is based in part on a calculation of risks, any information which reduces the range of each risk is helpful. If the distinction could be maintained between, on the one hand, exploration of realities and, on the other, threats for choosing a plea of not guilty, it would be best to allow the judge to explore realities. But the distinction is difficult to make, as illustrated by the facts in McGrath and Kimbrough.

Total elimination of judges' comments on sentences would, of course, decrease the dangers involved in this kind of inducement. However, even when the judge says nothing at all to the defendant, the constitutional problem of threatening the defendant may arise. One court has taken "judicial notice of the fact that trial courts quite generally impose a lighter sentence on pleas of guilty than in cases where the accused pleaded not guilty but has been found guilty by a jury." 61 The defendant, aware of a general but unarticulated policy of differing sentences based solely on plea entered may be viewed as having been threatened with punishment for going to trial.

60 In a footnote, the majority said: "As we view the transcript . . . it is far more consonant with a view of the trial judge as one who is not stern, overeager, or overbearing, determined to intimidate the defendant into pleading guilty . . . but rather of a seasoned and able judge sympathetic with the dilemma in which the defendant found himself and interested in seeing that the defendant fully understood precisely what faced both him and the judge in light of the realities of the situation." Id. at 314 n.3. The court seems to be making a peculiar comparison between the friendly McGrath trial judge, and the unsympathetic judges in Euziere and Tateo. To the dissenting judge, the same set of facts painted a picture of a trial judge who, by his statements, "added the element of compulsion which necessarily took from the defendant's subsequent guilty plea the voluntariness which our concept of due process requires that he possess." Id. at 322.

61 Dewey v. United States, 268 F.2d 124 (8th Cir. 1959). 
Elimination of this type of differential sentencing ${ }^{62}$ as a practice and policy could be one solution. This solution is more difficult to support here than in the case of judge comments. The argument is weaker because, although the threat-of-punishment factor remains, the threat-of-an-unfair-trial factor is either eliminated or sharply diluted. The judge who follows a general policy in sentencing at no time expresses a prejudice toward the individual defendant. Consequently, the threat of his being unfair in presiding at the trial is largely removed. This is so unless it can be successfully argued that the judge who follows a policy of differential sentencing harbors a prejudice against all defendants who go to trial. Even this argument is vitiated, however, if the policy is imposed by superior judicial authority or by statute.

A further difficulty would arise if differential sentencing were eliminated: Not all differing sentences that correspond to differences in pleas are based solely on the plea entered. ${ }^{63} \mathrm{~A}$ total elimination of

62 Differential sentencing refers, generally, to the imposition of differing sentences on defendants in essentially similar circumstances who plead differently. Within the category a distinction must be made between differential sentencing in which the differing sentences are based on the differences in plea and the instances in which the differences in sentences correspond to differing pleas but are based on some other factor. See note 63 infra.

There is no longer any question that judges sentence differentially. In 1963, in the federal courts, the following figures obtained:

Plea
Original plea of guilty
Not guilty, changed plea to guilty
Convicted by court
Convicted by jury

$\%$
Imprisoned
43.4
38.3
53.3
72.2

$\%$ Getting Year or more 31.7 26.7 40.4 57.6

Administrative Office of the U.S. Courts, Federal Offenders in the United States District Courts (1963). The figures remain relatively consistent when broken down by crime or federal judicial district. This is the first time official figures have been collected on differential sentencing in the federal courts.

These figures substantially confirm the poll of judges reported in Comment, 66 YALE L.J. 204 (1956). They suggest significant strategic consequences for the defendant. Clearly, a court trial is generally preferable to a jury trial unless there is some factor that increases probability of acquittal by the jury. No defendant should plead guilty immediately, but, rather, should plead not guilty, wait, and then change his plea. By playing hard-to-get, he receives an added benefit. The figures suggest (but do not prove) that the differentials are in fact offered, at least in part, in order to get pleas of guilty. The differences between defendants who plead guilty originally and those who change to a plea of guilty are the reverse of what a contrition theory would lead one to expect.

63 The practice of giving lenient sentences on guilty pleas and severe ones on conviction after trial ought to be prohibited as unconstitutional. The question has been litigated only rarely, though cases on the point seem to be increasing in frequency. The classic case is United States v. Wiley, 278 F.2d 500 (7th Cir. 1960), 267 F.2d 453 (7th Cir. 1959), 184 F. Supp. 679 (N.D. III. 1960). This multiplicity of opinions resultéd from a protracted disagreement between the trial judge and the 
differential sentencing aimed at those sentencing practices would also reach the cases in which the differences in sentence are a response to facts perceived about the defendant as he pleads. Many judges argue that a plea of guilty is evidence of contrition or ripeness for rehabili-

reviewing court over the appropriate sentence in the case. One of several co-defendants in this case decided to go to trial while his cohorts pleaded guilty. Although there was evidence that the defendant who went to trial was the "least guilty" of the group, he received the heaviest sentence. The reviewing court objected on another point 'but intimated that there was something seriously wrong with Wiley's sentence when compared with the others' sentences. 267 F.2d at 456. The trial judge imposed the same sentence as before, Wiley again appealed and the reviewing court again returned the case for reconsideration of the sentence, saying: "It is evident that the punishment imposed by the district court on Wiley was in part for the fact that he had availed himself of his right to trial, and only in part for the crime for which he was indicted." 278 F.2d at 504.

Appellate review and objection to a sentence that is imposed within the statutory sentencing limits and according to proper procedure is extraordinary. Nonetheless, the reviewing court in this case, without citation of authority for the proposition that the sentence was bad, did review and did object. Although its reasoning is not clear, the court clearly suggested that a sentence practice that in effect imposes punishment solely for going to trial rather than pleading guilty is objectionable.

The general proposition seems unassailable. Appellate courts, however, have generally refused to concern themselves with the problem. The difficulty in all of these cases is to determine what the basis of the sentence was. The differentials may be justified on numerous grounds other than the plea alone and it is almost impossible to tell what the basis is. It may be that Wiley presented facts which, to the reviewing court, were so clear an example of what should be forbidden that the extraordinary review was justified. Compare Johnson v. United States, 318 F.2d 855, 859 (8th Cir. 1963), where the reviewing court found, on facts quite similar to those in Wiley, "no substance to defendant's contention that he has been punished in part for insisting upon his right to be tried by a jury." The court distinguished IViley in part on the facts and concluded by saying "we do not reach the troublesome question of whether the fact that a defendant stands trial may be considered as a factor in determining the sentence." Id. at 859-60.

The way out of the Wiley-type situations for appellate courts appears to be to refuse to review the sentence at all. E.g., United States v. De Marie, 261 F.2d 477 (7th Cir. 1959). The courts simply observe that due process does not require similar sentences for co-defendants, even if they are being tried for the same crime. E.g., United States v. Vita, 209 F. Supp. 172 (E.D.N.Y. 1962); United States v. Litterio, 153 F. Supp. 329 (S.D. Tex. 1957), aff'd, 244 F.2d 956 (5th Cir.), cert. denied, 355 U.S. 849 (1957).

Despite the reticence of the courts, born of the difficulty in finding the basis of a particular sentence, the opinions suggest, sometimes weakly, that differential sentencing by the judge solely on the basis of differing pleas is not constitutional. Somewhat more abstract arguments support this conclusion. For example, "[T]o condone sentencing on this basis would be to undermine, by discouraging its exercise, a fundamental right of the accused-the right to trial by jury." Note, 109 U. PA. L. REv. 422, 426 (1961). For a full review of the problems of differential sentencing, plus strong arugments on both sides of the question, see Pilot Institute on Sentencing, 26 F.R.D. 231 (1959). The discussion focuses on tax cases. Should the policy be different with respect to economic and "white collar" crimes than with respect to more serious felonies such as robbery, murder or rape?

Differential sentencing can be imposed by statute. A New York statute reads: 
tation, thus requiring imposition of a more lenient sentence. ${ }^{64}$ While some skepticism is permissible with respect to most of these cases, tension does exist between the need to recognize genuine cases of contrition and the need to avoid the dangers of general policies of differential sentencing. This tension may be resolved by permitting differential sentencing only when a genuine case of contrition arises. The danger to the innocent defendant considering his plea would then only arise when the judge's recognition of contrition occurs so frequently as to reasonably induce the defendant to rely on such recognition in his own case. A judge who recognizes contrition so frequently as to give rise to a de facto policy of differential sentencing probably has an overly generous view of contrition. A policy of differential sentencing imposed by statute or superior judicial authority, ${ }^{65}$ which is supported by the contrition argument, is similarly indefensible.

\footnotetext{
"When the court and the district attorney consent, a defendant indicted for murder in the first degree may plead guilty to murder in the first degree with a sentence of life imprisonment, in which case the court shall sentence him accordingly." N.Y. PENAL CODE § 1045 (1963). The pressure on the defendant indicted for first degree murder in New York must be substantial. Perhaps it is so substantial that the statute ought not to stand. However, a defendant who goes to trial has the full protection of jury and judge and, in that sense, the statute is more like prosecutor inducements than judge inducements. Furthermore, the statute was probably passed in response to a nagging feeling that guilty pleas are not wholly reliable-or at least not as reliable as the trial determination of guilt-and that therefore the death penalty ought not be imposed unless the trial process first convicts. The statute is likely to encourage innocent defendants to plead guilty and thereby further decrease the reliability of the guilty plea, the very unreliability that may have spawned the statute to begin with. The constitutionality of this statute is a borderline question under the analysis suggested in this comment. See also Marder v. Massachusetts, 377 U.S. 407 (1964), which involved a state statute on traffic violations. Alleged violators are given the usual choice between pleading guilty and paying a small fine and foregoing trial, or going to trial and thereby exposing themselves to the possibility of greater punishment if found guilty. The Court dismissed per curiam for want of a substantial federal question, Justices Goldberg and Douglas dissenting. The statute presents a characteristic case of inducement to plead guilty and the Court would have been more helpful had it explained why there was no substantial federal question here.

64 One example of this appears in Wiley. In defending the sentence he had imposed, the trial judge said: "In sentencing Wiley, I seriously considered his prospects for rehabilitation. When he originally changed his plea from guilty to not guilty, there was no remorse in this man. [The other defendants] did stand conscience-stricken in repentance before the court." $184 \mathrm{~F}$. Supp. at 687. This and other grounds for differential sentencing are debunked in Note, 66 YALE L.J. 204, 206-07 (1956). See also Newman, Pleading Guilty for Considerations: A Study of Bargain Justice, 46 J. CRIM. L., G. \& P.S. 780, 784 (1956).

65 The New York statute, discussed in note 63 supra, is an example of this. Wiley, in its almost unbelievable richness, also provides an example of a policy of differential sentencing. The trial judge announced that it was his standing policy not to consider probation for defendants who went to trial. The reviewing court, on its review of the case, read the federal probation statute to require
} 
This analysis, revolving as it does around the impact of the judge's comments on the defendant, suggests that not all judicial comments require voiding of the resulting plea. Some threats will not have sufficient force to persuade the innocent defendant to plead guilty, either because the threatened sentence is not sufficiently severe or because the threat has been viewed by the defendant as a report rather than a threat of the realities. However, the administrative difficulties presented by rules requiring judicial distinction between "good" and "bad" judge comments would be substantial. The appellate courts would be faced with the task of probing deeply into the defendant's mind to determine what the specific impact of a specific inducement on a particular defendant was under given circumstances. While appellate courts are not to be saved the task of deciding difficult questions simply because they are difficult, where the determinations are difficult, substantial danger exists for the defendant that the appellate court will make a mistake. Unless there is a compelling need for making these determinations, they should be avoided.

That need does not exist. Given the permissibility of prosecutor-bargain inducements which produce sufficient guilty pleas, added judicial inducements are unnecessary. Even now the defendant receives a double benefit: The prosecutor first dismisses some counts in exchange for a plea of guilty and then the judge sentences leniently on that plea. The criminal process does not require the second barrel of the doublebarrel inducement. Resolution of the tension between the dangers of and the need for guilty plea inducements does not compel the allowance of judicial inducements of any kind. Therefore, the mere presence of a judicial inducement to plead guilty should require reversal. As a result, most acceptable induced guilty pleas will be the consequence of inducements of the prosecutor-bargain type.

The problem of induced guilty pleas illustrates a compelling problem that pervades the criminal process: the tension between the need for effective and efficient administration on the one hand, and the need for protection of the constitutional rights of the defendant on the other. Pursuit of one invades the other. Resolution cannot be accomplished by arbitrary rules and vague concepts. Rather, further analysis of the ways in which specific administrative tools invade specific rights is needed. Specially contoured rules may then be developed which will respond to the competing needs of a fair and effective system of criminal law administration.

consideration of probation in every case, a probably tortured reading of that statute. The trial court proceeded to consider probation, to reject it, and to reimpose the original sentence. 